\title{
ナトリウムアミドを用いた $\boldsymbol{m}$-トルエンスルホン酸塩 のアミノ化反応 ${ }^{12)}$
}

(1976 年 5 月 28 日受理)

\author{
奈良 蜸一* - 真 鍋修**
}

\section{1 緒言}

著者らはこれまでの研究で芳香族スルホン酸塩とナトリウムフ ミドを液体アンモニア，モノフルキルアミンおよび芳香族第一ア ミン中で加熱加压反応を行ない，相当する芳香族第一アミン方， 菸香族アルキルアミン4，ジアリールフミンのがいずれる収率よ く得られること、またこれらのアミノ化反応ではベンザィン機構 によるアミノ基の転移のような異性化の起こらないことを明らか にした。

Kovacic $5^{6)} \mathrm{AlCl}_{3}$ の存在下ヒドロキシルフミン-oースルホ ン酸やアルキルヒドロキシルフミンなどとトルエンとの反応によ る $m$ ートルイジンの合成を報告しているが，いずれの場合もの-特 よび pートルイジンの生成量が多く，また全トルイジン収率むよ くない。 $m$-トルイジンの合成法としては $m$ ーニトロトルェンの還 元による方法がより一般的であるが，トル土ンから $m$ ーニトトト ルェンの合成が困難なため実用上問題が残されている。

本報ではトルエンのスルホン化，桑転移，部分加水分解によっ て製した $m$-トルエンスルホン酸カリウム（以下 $m$-TSK と略記

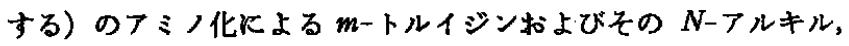
$N$-フェニル誘導体の合成について検討した結果を報告する。

\section{2 实駼}

\section{1 試 料}

原料の m-TSK はトルエンのスルホン化, 熱転移, 部分加我 分解によって得られた $\left(m-\mathrm{TSK}_{1}\right.$, 異性体組成比 $\left.0: m: p=0.8: 90.7: 8.5\right)$ を製し, これを水から再結晶して $m-\mathrm{TSK}_{2}(0: m: p=0.3: 99.0: 0.7)$ と した。合成法の詳細については别に報告する゙。

ナトリウムアミド，モノアルキルフミン，フニリンは市販品を 使用した。

\section{$2.2 m$-TSK のアミノ化}

2.2 .1 第一极了ミノ化 (m-トルイジンの合成): $m$-TSK 無 水物 $(0.05 \mathrm{~mol})$ と 2.6〜3.6 倍モルのナトリウムアミドを液体 アンモニア $80 \mathrm{~m} l$ ととるにオートクレーブ中で装 1 の反応条件 にしたがって加压アミノ化を行なった。反応後フンモニてを留

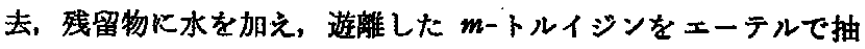
出し、ガスクロマトグラフィーおよびジアり゙滴定によって定量し た。アミノ化の反応率は副生した亜硫酸塩をヨウ素法で定睘して 算出した。

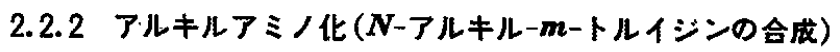
$N$-エチル-m-トルイジン: エチルアミン $80 \mathrm{ml}, m-\mathrm{TSK}_{2} 0.05$

Table 1 Reaction of $m$-TSK with sodium amide in liq. $\mathrm{NH}_{3}$

\begin{tabular}{|c|c|c|c|c|c|c|}
\hline \multirow{2}{*}{$m$-TSK } & \multirow{2}{*}{$\begin{array}{l}\text { Molar ratio } \\
\mathrm{NaNH}_{2} / \mathrm{TSK}\end{array}$} & \multirow{2}{*}{$\begin{array}{c}\text { Temp. } \\
\left({ }^{\circ} \mathrm{C}\right)\end{array}$} & \multirow{2}{*}{$\underset{\text { (hr) }}{\text { Time }}$} & \multirow{2}{*}{$\begin{array}{c}\text { Conversion } \\
(\%)\end{array}$} & \multirow{2}{*}{$\begin{array}{c}\text { Toluidine } \\
\text { yield } \\
(\%)\end{array}$} & Toluidine ratio \\
\hline & & & & & & $o: m: p$ \\
\hline \multirow{6}{*}{$m-\mathrm{TSK}_{1}$} & 2.6 & 120 & 8 & 72.4 & 65 & $0.3: 98.0: 1.7$ \\
\hline & 3.3 & 105 & 10 & 75.9 & 69 & $0.4: 97.3: 2.3$ \\
\hline & 3.3 & 120 & 8 & 82.3 & 73 & $0.7: 95.8: 3.5$ \\
\hline & 3.3 & 130 & 8 & 89.8 & 80 & $0.5: 94.2: 5.3$ \\
\hline & 3.3 & 150 & 4.5 & 91.1 & 77 & $0.6: 93.1: 6.3$ \\
\hline & 3.6 & 120 & 8 & 85.0 & 76 & $0.5: 95.0: 4.5$ \\
\hline \multirow{2}{*}{$m-\mathrm{TSK}_{2}$} & 3.3 & 115 & 9 & 94.6 & 89 & $0: 99.0: 0.1$ \\
\hline & 3.3 & 130 & 7 & 96.1 & 91 & $: 99.7: 0.3$ \\
\hline
\end{tabular}

TSK $=$ Toluenesulfonate, potassium. $m-\operatorname{TSK}_{1}(o: m: p$ ratio $=0.8: 90.7: 8.5) ; m-\mathrm{TSK}_{2}(o: m: p$ ratio $=0.3: 99.0: 0.7)$. $m$-TSK $: 0.05 \mathrm{~mol}$, liq. $\mathrm{NH}_{3}: 80 \mathrm{ml}$.

1）この報文を“芳香族化合物のアミ/化に関する研究（第 5 報)”とする.

2）前報(第 4 報)，奈良贅一，渭東祥高，真鍋 修，日化，1974， 2449.

* 大阪市立工業研究所, 530 大阪古北区北扇町

** 長㱦大学工学部工業化学科, 852 鹿䐀市文教町

3）奈良蜸一，真鍋 修，日化，1974，1522.

4）奈良堅一，真鍋 胳，日化，1974，1704.
5）奈良賢一，真鍋 抮、日化，1974，1808.

6) P. Kovacic, R. P. Bennett, J.Am. Chem. Soc., 83, 221 (1961) ; P. Kovacic, J. L. Foote, ibid., 83, 743(1961) ; P. Kovacic, J. L. Foote, R. P. Bennett, ibid., 84, 759 (1962).

7）山本宗一，真鍋 修，日本化学会第 32 春乎年会講演菒， $N$, p. 1958(1975)；日化，投稿中. 
Table 2 Alkylamination of $m$-TSK

\begin{tabular}{|c|c|c|c|c|c|c|c|}
\hline $\begin{array}{c}\mathrm{RNH}_{2} \\
\mathrm{R}=\end{array}$ & $\begin{array}{l}\text { Molar ratio } \\
\mathrm{NaNH}_{2} / \mathrm{TSK}\end{array}$ & $\begin{array}{c}\text { Temp. } \\
\left({ }^{\circ} \mathrm{C}\right)\end{array}$ & $\begin{array}{c}\text { Time } \\
(\mathbf{h r})\end{array}$ & $\begin{array}{c}\text { Conversion } \\
(\%)\end{array}$ & $\begin{array}{c}\text { Amine ratio } \\
m-\mathrm{AT}: \mathrm{T}\end{array}$ & 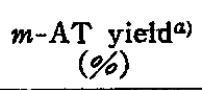 & $\begin{array}{c}\mathrm{R}_{2} \mathrm{NH} \text { yield } \\
(\%)\end{array}$ \\
\hline \multirow{5}{*}{$\mathbf{E t}$} & 3.0 & 140 & 10 & 94.5 & $97: 3$ & 87 & - \\
\hline & 3.3 & 150 & 7 & 98.0 & $94: 6$ & 91 & - \\
\hline & 3.3 & 140 & 8 & 97.1 & $96: 4$ & 92 & - \\
\hline & 3.6 & 140 & 8 & 98.3 & $94: 6$ & 90 & - \\
\hline & 4.2 & 140 & 8 & 99.5 & $93: 7$ & 89 & - \\
\hline \multirow{5}{*}{$\mathrm{Bu}$} & 3.3 & 110 & 15 & 90.1 & $99: 1$ & 82 & - \\
\hline & 3.3 & 145 & 9 & 97.6 & $98: 2$ & 91 & 9 \\
\hline & 3.3 & 165 & 6 & 99.5 & $93: 7$ & 89 & 32 \\
\hline & 3.6 & 145 & 9 & 98.5 & $97: 3$ & 87 & 14 \\
\hline & 4.2 & 145 & 8 & 98.7 & $96: 4$ & 85 & 19 \\
\hline
\end{tabular}

$m-\mathrm{AT}=N$-Alkyl-m-toluidine, $\mathrm{T}=$ Toluidine.

a) Yields of $m-\mathrm{AT}$ and $\mathrm{R}_{2} \mathrm{NH}$ are based on $m$-TSK and $\mathrm{NaNH}_{2}$ used, respectively. $m$-TSK : $0.05 \mathrm{~mol}, \mathrm{RNH}_{2}: 80 \mathrm{ml}$.

Table 3 Phenylamination of $m$-TSK

\begin{tabular}{lccccc} 
Solvent & $\begin{array}{c}\text { Molar ratio } \\
\mathrm{NaNH}_{2} / \mathrm{TSK}\end{array}$ & $\begin{array}{c}\text { Temp. } \\
\left({ }^{\circ} \mathrm{C}\right)\end{array}$ & $\begin{array}{c}\text { Time } \\
(\mathrm{hr})\end{array}$ & $\begin{array}{c}\text { Conversion } \\
(\%)\end{array}$ & $\begin{array}{c}N \text {-Phenyl-m-toluidine } \\
\text { yield }(\%)\end{array}$ \\
\hline Aniline & 3.5 & 225 & 6 & 95.4 & 92 \\
Aniline & 3.3 & 185 & 8 & 92.3 & 90 \\
DMA $^{a)}$ & 3.3 & 220 & 7 & 92.7 & 90 \\
Xylene $^{a)}$ & 3.5 & 215 & 8.5 & 90.6 & 88
\end{tabular}

a) Molar ratio of aniline $/ m-\mathrm{TSK}=4.0$.

$m$-TSK : $0.05 \mathrm{~mol}$, Solvent $: 80 \mathrm{ml}$.

mol, ナトリウムフミド 0.15〜0.21 mol をオートクレーブK入 れ，最初 $70 \sim 80^{\circ} \mathrm{C} ， 3 \sim 5$ 時間の加圧，加熱反応ののb昇温し 表 2 の条件でアミノ化を行なった。反応後エチルアミンを留去, 牫留物に水を加え遊離した $N$-エチルーmートルイジンをエーテル で抽出した。

N-ブチルーm-トルイジン: ブチルアミン $80 \mathrm{ml}$ とテトリウム フミド $0.17 \sim 0.21 \mathrm{~mol}$ を $200 \mathrm{ml}$ のナスフラスコに入れ, 還流 温度で $4 \sim 5$ 時間脱フンモニア反応後, 過剩のブチルアミンを留 去, 残留するナトリウムプチルフミドを $80 \mathrm{ml}$ のブチルフミン とともにオートクレーブに入れ，さらに $m-\mathrm{TSK}_{2} 0.05 \mathrm{~mol}$ ，を加 え，表 2 の条件で加圧加熱反応を行なった。反応後エナルアミノ 化と同様の操作により $N$-ブチルーmートルイジンを製した。また 最初から m-TSK 2 をオートクレーブK入れ，常圧で脱アンモニ ア反応後昇温し，加圧加熱反応を行なってるほぼ同じ結果が得ら れた。反応率はヨウ来法により，また $N$ ーアルキルー正ートルイシ ン収率はェーテル抽出物を蒸留し, 业硝酸法により算出した。 $m$ トルイシンと $N$-アルキルーmートルイジンとの比率（アミン比） はガスクロマトグラフィーによって求めた。

2.2.3フェニルアミノ化 $\left(\boldsymbol{N}-\boldsymbol{J}_{ェ}\right.$ ニル-m-トルイジンの合 成):オートクレーブ中，常玱でアニシンとナトリウムアミド (0.165 0.175 mol) の脱アンモニア反応によってナトリウムフ ニリドを製し，これと $m-\mathrm{TSK}_{2}(0.05 \mathrm{~mol})$ をアニリン, $N, N-$ ジメチルフニリン (DMA), キシンン溶媒中表 3 の条件で常压あ るい仕加圧反応によりフェニルフミノ化を行なった。反応率は副 生した亜硫酸塩をヨウ素法で定量し，アミン取率は生成したジフ リールアミン蒸留物の重量お゙びガスクロマトグラフィーから求 めた。

\section{3 結 果と考察}

\section{1 第一級了ミノ化}

液体フンモニフ中 $m$-TSK のナトリウムアミドによる第一級 アミノ化の結果を表 1 に示す。すでに著者らはTS 塩のアミノ化 の反応性が $0<p<m$ の順に増大することを明らかにしたが， この実験からわかるように，異性体を含むTSK を使用した場合 でも瑷和な反応条件でアミノ化を行ならと，反応率は低下する が，mートルイジンをかなり選択的に合成することができた。ま た反応率はナトリウムアミドが多いほど、あるいは反応温度が高 くなるはど增加するが，アミン取率は温度が高くなると最大值を 程て低下する傾向がみられた。これらのことから選択的に $m$-ア ミノ化を行ならためには，たとえば 3.3 倍モルのナトリウムフミ ドを用い，115〜 $120^{\circ} \mathrm{C} ， 8 \sim 9$ 時間の反応条件が適当であること がかかった。

\section{2 アルキルアミノ化}

m-TSK のエチルアミノ化およびブナルフミノ化の結果を表 2 に示す。この反応は(1)式の反応で得られるナトリウムアルキル アミドの $m$-TSK への求核置換反応(2)式によるものであるが, 同時に(3)式の第一級アミノ化反応によって若干の $m$-トルイジ の副生することがわかった。そこでナトリウムアルキルアミドを いったん分離し，これと $m$-TSK をアルキルアミン中で反応さ せるか，あるいは最初から m-TSK をナトリウムアミド，アル

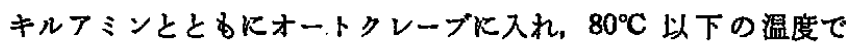
（1）式の反応を行なったあと，高温，加压反応を行ならことによ って $m$-トルイジンの副生を抑制することができた。またアミノ 化反応の洫度が高いか，あるいはナトリウムフミドの使用量の多 い場合は反応率が离くなるが，フルキルアミノ化の選択性は低下 した。またこの場合,ブチルアミノ化に拈いては(4)式の反応に 
よるジブチルフミンの生成すみられた。

$$
\begin{aligned}
\mathrm{RNH}_{2}+\mathrm{NaNH}_{2} \rightleftarrows \mathrm{RNHNa}+\mathrm{NH}_{3} \\
\mathrm{ArSO}_{3} \mathrm{~K}+2 \mathrm{RNHNa} \\
\longrightarrow \underset{\mathrm{R}}{\mathrm{Ar}}>\mathrm{NNa}+\mathrm{RNH}_{2}+\mathrm{NaKSO}_{3} .
\end{aligned}
$$

$\mathrm{ArSO}_{3} \mathrm{~K}+2 \mathrm{NaNH}_{2}$

$$
\longrightarrow \mathrm{ArNHNa}+\mathrm{NH}_{3}+\mathrm{NaKSO}_{3}
$$

$\mathrm{RNH}_{2}+\mathrm{RNHNa} \rightleftharpoons \mathrm{R}_{2} \mathrm{NNa}+\mathrm{NH}_{3}$

$$
\text { (ただし、Ar=mートリル) }
$$

\section{3 フェニルアミノ化}

アニリンとナトリウムフミドから製したナトリウムフミドによ
る $m$-TSK のフェニルフミノ化の結果を表 3 亿示す。反応溶媒 としてアニリン，DMA，キシレンのいずれを使用した場合る取率 よく $N$-フェニルーmートルイジンが得られた。また反応によって 生成したエーテル抽出物のガスクロマトグラフィー分析の結果, mートルイジンは認められす， フルキルフミノ化の場合と異なり， この反応では第一級つミノ化はまったく起こらないことがかかっ た。これはナトリウムアミドに対するアニリンとフルキルアミン との酸性度の差によるすのと考えられる。

(1975 年 4 月, 日本化学会第 32 春季年会発表)

\title{
Amination of $\boldsymbol{m}$-Toluenesulfonate with Sodium Amide
}

\author{
Ken-ichi Nara* and Osamu Manabe** \\ * Osaka Municipal Technical Research Institute; \\ Kita-ogimachi, Kita-ku, Osaka-shi 530 Japan \\ ** Department of Chemical Engineering, Faculty of \\ Engineering, Nagasaki University; Bunkyo- \\ machi, Nagasaki-shi 853 Japan
}

Amination of potassium $m$-toluenesulfonate ( $m$-TSK) with sodium amide in liquid ammonia at $130^{\circ} \mathrm{C}$ for $7 \mathrm{hr}$ gave $m$-toluidine in $91 \%$ yield. Higher selectivity for meta amination was acquired at somewhat a lower temperature and by a longer time, for example at $115^{\circ} \mathrm{C}$ for $9 \mathrm{hr}$ it was as high as $99.9 \%$. Sodium alkylamide ( $R=E t, B u)$ which was prepared by the reaction of $\mathrm{RNH}_{2}$ with sodium amide, reacted with $m$-TSK in $\mathrm{RNH}_{2}$ at $140 \sim 165^{\circ} \mathrm{C}$ for $6 \sim 10$ hr to give $85 \sim 91 \%$ of $N$-alkyl-m-toluidine accompanied with small amounts of $m$-toluidine and $\mathrm{R}_{2} \mathrm{NH}(\mathrm{R}=\mathrm{Bu})$. Phenylamination of $m$-TSK with sodium anilide in aniline, DMA or xylene at $185 \sim 225^{\circ} \mathrm{C}$ for $6 \sim 8.5 \mathrm{hr}$ gave $N$-phenyl-m-toluidine in $88 \sim 92 \%$ yield, and the formation of $m$-toluidine was not observed in this case.

$t$ Studies on the Amination of Aromatic Compounds. V. 